\title{
Oral delivery of glucagon-like peptide-1 in a modified polymer preparation normalizes basal glycaemia in diabetic $d b / d b$ mice
}

\author{
J.W. Joseph ${ }^{1}$, J. Kalitsky ${ }^{1}$, S. St-Pierre ${ }^{2}$, P. L. Brubaker ${ }^{1}$ \\ ${ }^{1}$ Department of Physiology, University of Toronto, Toronto, Ontario, Canada \\ ${ }^{2}$ Department of Chemistry, University of Quebec in Montreal, Montreal, Quebec, Canada
}

\section{Abstract}

Aims/hypothesis. The insulinotropic hormone, glucagon-like peptide-1 has been proposed for the treatment of patients with Type II (non-insulin-dependent) diabetes mellitus. As glucagon-like peptide-1 is rapidly cleaved at $\mathrm{L}-\mathrm{ala}^{2}$ by dipeptidylpeptidase IV, D-ala ${ }^{2}$-glucagon-like peptide-1 was synthesized and shown to have dipeptidylpeptidase IV resistance in vitro and enhanced bioactivity in mice during an oral

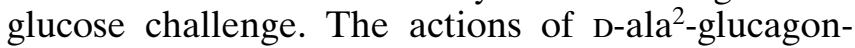
like peptide- 1 were, however, lost within $4 \mathrm{~h}$ of injection, thus necessitating frequent and invasive treatment if it is to be used therapeutically. To circumvent this problem, a microsphere of $\mathrm{D}^{-a^{2}}{ }^{2}$-glucagon-like peptide-1 that could be given orally was developed. Methods. We encapsulated D-ala ${ }^{2}$-glucagon-like peptide-1 in poly(lactide-co-glycolide)- $\mathrm{COOH}$ with olive oil as a filler, using phase inversion. The microspheres were tested in vivo by oral gavage in mice at $t=0 \mathrm{~h}$ followed by repeated oral glucose tolerance tests at $\mathrm{t}=0,4$ and $8 \mathrm{~h}$.
Results. The D-ala ${ }^{2}$-glucagon-like peptide-1-microspheres lowered the glycaemic response to the $4 \mathrm{~h}$ oral glucose challenge in both normal CD1 and diabetic $d b / d b$ mice, by $41 \pm 12 \% \quad(p<0.001)$ and $27 \pm 5 \%(p<0.001)$, respectively and by $19 \pm 11 \%$ $(p<0.05)$ and $28 \pm 4 \%(p<0.001)$, respectively during the 8 -h test. At $4 \mathrm{~h}$ after the oral gavage, basal glycaemia in the diabetic mice was reduced from $13 \pm 1 \mathrm{mmol} / \mathrm{l}$ to $10 \pm 1 \mathrm{mmol} / \mathrm{l}$ and was reduced further $8 \mathrm{~h}$ after treatment from $12 \pm 1 \mathrm{mmol} / \mathrm{l}$ to $8 \pm 1 \mathrm{mmol} / \mathrm{l}(p<0.05)$. Giving D-ala ${ }^{2}$-glucagon-like peptide-1 alone orally had no effect on glycaemia. Conclusion/interpretation. The data presented here suggest that a similar microsphere preparation could be useful in the delivery of glucagon-like peptide-1 to patients with Type II diabetes. [Diabetologia (2000) 43: 1319-1328]

Keywords OGTT, peptide delivery system, GLP-1, analog, PLGA-COOH, oral microspheres.
Glucagon-like peptide-1 (GLP-1) has been proposed as a therapeutic agent for the treatment of Type II (non-insulin-dependent) diabetes mellitus because of its ability to stimulate glucose-dependent insulin

Received: 3 May 2000 and in final revised form: 3 July 2000

Corresponding author: P. Brubaker, PhD, Department of Physiology, 1 King's College Circle, Medical Science Building, Room 3366, Toronto, Ontario, M5S 1A8 Canada

Abbreviations: GLP-1: glucagon-like peptide-1, DP IV: dipeptidylpeptidase IV, PLGA-COOH: poly(lactide-co-glycolide)carboxylic acid. release and stimulate beta-cell insulin gene expression [1-6]. Glucagon-like peptide-1 has also been reported to act on glucose-resistant beta cells to enhance their responsiveness to this nutrient secretagogue [7]. Additional glycaemic-lowering biological activities of GLP-1 that complement its effects on the beta cell include inhibition of both glucagon secretion and gastric emptying [6]. A key factor limiting the therapeutic potential of GLP-1 is, however, its very short half-life in vivo $(0.9 \mathrm{~min},[8])$. The major enzyme contributing to this inactivation of GLP-1 is dipeptidylpeptidase IV (DP IV), which cleaves GLP-1 at the N-terminal penultimate alanine resi- 
due, thereby removing a His ${ }^{1}-\mathrm{Ala}^{2}$ dipeptide [8-10]. The clinical importance of the short half-life of GLP-1 was highlighted in a recent in vivo study in which GLP-1 was infused overnight in patients with Type II diabetes, thereby restoring fasting blood glucose concentrations to normal. When the infusion was stopped in the morning, the effects of GLP-1 on insulin, glucagon and blood glucose were lost, suggesting that GLP-1 is required to be provided continuously for the treatment of Type II diabetes [11].

A number of different approaches have been developed that bypass the digestive system, thereby permitting non-invasive, systemic delivery of peptides and other therapeutic agents [12-14], including nasal sprays for vasopressin and insulin, and mucosal/buccal dosage forms of both insulin and GLP-1 [15-19]. Although these are relatively successful techniques for peptide delivery, these approaches have limitations that can lead to poor patient compliance, including the potential for causing tissue damage at the site of delivery [12-14, 20]. Alternative, less invasive routes of peptide delivery therefore continue to be a focus of investigation.

Recently, effective methods for encapsulating peptides and other drugs into orally available, biocompatible microspheres have been developed $[12,13$, $21,22]$. In our study, a new approach to the preparation of orally available peptides is described, using GLP-1 as the prototypic peptide. To reduce the inactivation of GLP-1, an analogue of GLP-1 (D-ala ${ }^{2}$ GLP-1) that was designed to be resistant to DP IVmediated degradation was developed. The results of this study indicate that encapsulation of $\mathrm{D}$-ala ${ }^{2}$-GLP1 into microspheres composed of a commercially available, biocompatible, biodegradable polymer, poly(lactide-co-glycolide)-COOH (PLGA-COOH) and olive oil as a filler, permits delivery of therapeutic concentrations of D-ala ${ }^{2}$-GLP-1 to normal CD1 and diabetic $d b / d b$ mice.

\section{Materials and methods}

Materials. Human placental DP IV was obtained from Calbiochem-Novobiochem (La Jolla, Calif., USA), poly(DL-lactideco-glycolide-COOH; 50/50) from Birmingham Polymers (PLGA-COOH, $\mathrm{M}_{\mathrm{w}} \sim 11,500 \mathrm{M}_{\mathrm{r}}$; Birmingham, Ala., USA), diprotin A from Calbiochem (San Diego, Calif., USA) and GLP$1^{(7-36) \mathrm{NH} 2}$ from Bachem California (Torrance, Calif., USA). Dala $^{2}$-GLP-1 was synthesized by the solid-phase method [23] using the Fmoc chemistry, and purified by high-performance liquid chromatography (HPLC), as described previously [24].

In vitro analysis of $\mathrm{D}-a_{1}{ }^{2}-G L P-1$ degradation by $D P I V$. Incubation of $0.125 \mathrm{mU}$ of DP IV (specific activity $=5000 \mathrm{mU} / \mathrm{mg}$ protein) with $33 \mu \mathrm{g} \mathrm{GLP-1}$ (control) or D-ala ${ }^{2}-\mathrm{GLP}-1$ for 3,8 or $24 \mathrm{~h}$ was done at $37^{\circ} \mathrm{C}$ in phosphate-buffered saline (PBS). The reaction was quenched by addition of $200 \mu \mathrm{g}$ of diprotin A. The elution position of peptide after incubation with DP IV was compared with that of untreated peptide by reversed- phase HPLC on a $\mathrm{C}_{18} \mu$ Bondapak column (Waters Associates, Milford, Mass., USA) with a linear gradient of 45-85\% solvent B (solvent A: $0.1 \% o$-phosphoric acid and $0.3 \%$ triethylamine; and solvent B: $40 \%$ solvent $\mathrm{A}$ and $60 \%$ acetonitrile) over $55 \mathrm{~min}$ [25]. We used UV absorption at $214 \mathrm{~nm}$ to detect peptides.

Microsphere preparation. Microspheres were prepared using a modification of the phase inversion method described previously [21]. In brief, PLGA-COOH $(6.25 \mathrm{mg} / 0.5 \mathrm{ml}$ methylene chloride) was mixed with $7 \mu \mathrm{l}$ of olive oil (density $0.91 \mathrm{~g} / \mathrm{ml}$ ) and then rapidly added to $25 \mu \mathrm{l} d d \mathrm{H}_{2} \mathrm{O}$ in a borosilicate glass tube, without (empty microspheres) or with $250 \mu \mathrm{g}$ peptide (final amounts $=48 \%$ PLGA-COOH, $50 \%$ olive oil and $2 \%$ peptide). The mixture was vortexed for $5 \mathrm{~s}$ and then rapidly poured into $50 \mathrm{ml}$ of unstirred petroleum ether, resulting in the spontaneous formation of microspheres. This was allowed to air-dry in a fume hood for $3.5 \mathrm{~h}$ and then the microspheres were harvested by scraping with a razor blade. Microspheres were stored under desiccant at $-20^{\circ} \mathrm{C}$ and were resuspended in an aqueous solution by probe sonication before use. The average size of the microspheres was $1.0 \pm 0.1 \mu \mathrm{m}$ after sonication, as measured using both a Nicomp 370/Autodilute Submicron Particle Sizer (Pacific Scientific Instruments Div., Silver Springs, Md., USA; courtesy of Dr. X. Y. Wu, University of Toronto, Toronto, Ont, Canada) and transmission electron microscopy.

Oral glucose tolerance test (OGTT). Female CD1 mice (6-8 weeks old; Charles River Canada, Montreal, Quebec, Canada) and female $d b / d b$ mice (9-10 weeks old; Jackson Laboratories, Bar Harbor, Me., USA) were housed under a light/ dark cycle of $12 \mathrm{~h}$ and were fasted for $16-17 \mathrm{~h}$ before the day of experimentation. All experiments were initiated between 0900 and 1000 hours. Mice were given $1.5 \mathrm{mg}$ of glucose per gram of body weight orally in water (vehicle) through a gastric gavage tube at $\mathrm{t}=0 \mathrm{~min}$ and blood was collected from a tail vein at $\mathrm{t}=0,10,20,30,60,90$ and $120 \mathrm{~min}$ for measurement of glycaemia using a One Touch Basic glucose meter (Lifescan Canada, Burnaby, British Columbia, Canada). In some experiments, OGTTs were repeated at $\mathrm{t}=4$ and $8 \mathrm{~h}$. Empty or D-ala ${ }^{2}$ GLP-1-containing microspheres were given orally with the glucose gavage at $\mathrm{t}=0 \mathrm{~min}$ or $\mathrm{D}-\mathrm{ala}^{2}-\mathrm{GLP}-1(5-10 \mu \mathrm{g})$ was injected s.c. or i.p. at $\mathrm{t}=0,4$ or $8 \mathrm{~h}$. All animal protocols were approved by the University of Toronto Animal Care Committee.

Gastric emptying. Gastric emptying was measured in $\mathrm{CD} 1 \mathrm{mice}$ by addition of $190 \mathrm{MBq}$ of 3-O-Methyl-D- $\left[1-{ }^{3} \mathrm{H}\right]$ glucose to the glucose gavage during repeated OGTTs in CD1 mice [26]. Blood samples were collected into a microhematocrit capillary tube and centrifuged to collect plasma for measuring $\mathrm{cpm}$ in a scintillation counter.

Circulating bioactive GLP-1 concentrations. To permit adequate sampling size for assay of GLP-1 concentrations, longterm cannula with PE-50 tubing (Itramedic, Parsippany, N. J., USA) were inserted into the carotid artery (for blood sampling) and jugular vein (for re-infusion of erythrocytes in heparinized saline) of male Wistar rats (Charles River, Canada). After 2 to 5 days' recovery from surgery, rats were fasted overnight and vehicle, empty microspheres or D-ala ${ }^{2}$-GLP-1-microspheres were given by oral gavage at $\mathrm{t}=0 \mathrm{~h}$. Blood samples were collected into a $10 \%$ volume of Trasylol:EDTA:Diprotin A $\left(5000\right.$ kallikrein-inactivating units: $12 \mathrm{mg} \cdot \mathrm{ml}^{-1}$ : $\left.0.1 \mathrm{mmol} \cdot \mathrm{l}^{-1}\right)$ at $\mathrm{t}=0 \mathrm{~h}$ and at $1 \mathrm{~h}$ intervals thereafter for $8 \mathrm{~h}$. Plasma was stored at $-20^{\circ} \mathrm{C}$ before analysis for bioactive 
GLP-1 concentrations using a Linco Elisa kit (Linco Research, St. Charles, Mo., USA). Analysis of D-ala ${ }^{2}$-GLP-1 in this twosite sandwich assay (e.g. N-terminal and C-terminal) showed only $8.8 \%$ cross-reactivity compared with the native peptide.

Perfused pancreas. Mice were fasted overnight and anaesthetized with $80 \mathrm{mg} / \mathrm{kg}$ sodium pentobarbital. PE-10 tubing (Intramedic) was used to cannulate the aorta and portal vein, and the duodenum with all associated blood vessels was tied off $5 \mathrm{~cm}$ below the pyloric sphincter. The pancreas was perfused at $750 \mu \mathrm{l} / \mathrm{min}$ through the aorta with Krebs-Ringer-2\% BSA-3\% dextran which had been gassed with $95 \% \mathrm{O}_{2} / 5 \% \mathrm{CO}_{2}$ to achieve a constant $\mathrm{pH}$ of 7.4 [27]. The pancreas was perfused sequentially with $1.4 \mathrm{mmol} / 1$ glucose $(5 \mathrm{~min}), 20 \mathrm{mmol} / 1$ glucose $(10 \mathrm{~min}), 20 \mathrm{mmol} / 1$ glucose $\pm 1 \mathrm{nmol} / 1 \mathrm{D}-\mathrm{ala}^{2}-\mathrm{GLP}-1$ (20 min) and $20 \mathrm{mmol} / 1$ glucose $(10 \mathrm{~min})$, for a total perfusion period of $45 \mathrm{~min}$. We collected 1-min fractions from the portal vein for direct insulin radioimmunoassay (RIA). At the end of the experiment, the pancreas was homogenized in $5 \mathrm{ml}$ of $1 \mathrm{~N} \mathrm{HCl}$ containing $5 \% \mathrm{HCOOH}, 1 \%$ trifluoroacetic acid and $1 \% \mathrm{NaCl}$ and the peptides were collected by reversed-phase extraction on a C18 SepPak cartridge (Waters Associates, Milford, Mass., USA). Extracts were dried in a vacuum before RIA for insulin. Insulin RIA was done as previously described [28]. To account for individual variations in pancreatic insulin content, insulin secretion in the perfused pancreas experiments was normalized for total pancreatic insulin content.

Statistics. Basal glycaemia was defined as the blood glucose concentration at $\mathrm{t}=0,4$ and $8 \mathrm{~h}$, measured immediately upon oral treatment with glucose in the OGTT. Glycaemic area under the curve (AUC) for each OGTT was calculated by the trapezoid rule using either absolute blood glucose concentrations or the delta from basal concentrations. Statistical significance was assessed by ANOVA with $n-1$ custom hypotheses tests or by Tukey's studentized range test, as appropriate, using a Statistical Analysis System program (SAS Institute, Cary, N.C., USA). All data are expressed as the means \pm SEM.

\section{Results}

In vitro and in vivo analyses of $\mathrm{D}-a l a^{2}-G L P-1$. To establish whether the GLP-1 analogue, D-ala ${ }^{2}$-GLP-1, is resistant to the actions of DP IV, native GLP-1 and D-ala ${ }^{2}$-GLP-1 were incubated with DP IV for 3, 8 or $24 \mathrm{~h}$ in vitro and the peptides were separated by HPLC. After $3 \mathrm{~h}$ of incubation with DP IV, GLP-1 showed a 1-minute shift in elution position and this was consistent for the incubation periods of 8 and $24 \mathrm{~h}$ (Fig. 1). In contrast, D-ala ${ }^{2}$-GLP-1 showed no change in elution position over $24 \mathrm{~h}$ of incubation with DP IV $(p<0.05)$, consistent with the hypothesis that substitution of $\mathrm{L}$-ala ${ }^{2}$ with $\mathrm{D}-\mathrm{ala}^{2}$ in GLP-1 confers resistance to DP IV-mediated cleavage.

The biological activity of D-ala ${ }^{2}$-GLP-1 in vivo was established by s.c. injection into CD1 mice followed by measurement of changes in the glycaemic response to an OGTT (Fig. 2). In comparison with vehicle-treated mice, native GLP-1 $(10 \mu \mathrm{g})$ reduced the glycaemic AUC by $38 \pm 9 \%(p<0.05)$. Treatment wtih D-ala ${ }^{2}-$ GLP-1 $(10 \mu \mathrm{g})$ also reduced the AUC compared with controls, by $115 \pm 14 \% ; p<0.001$ )
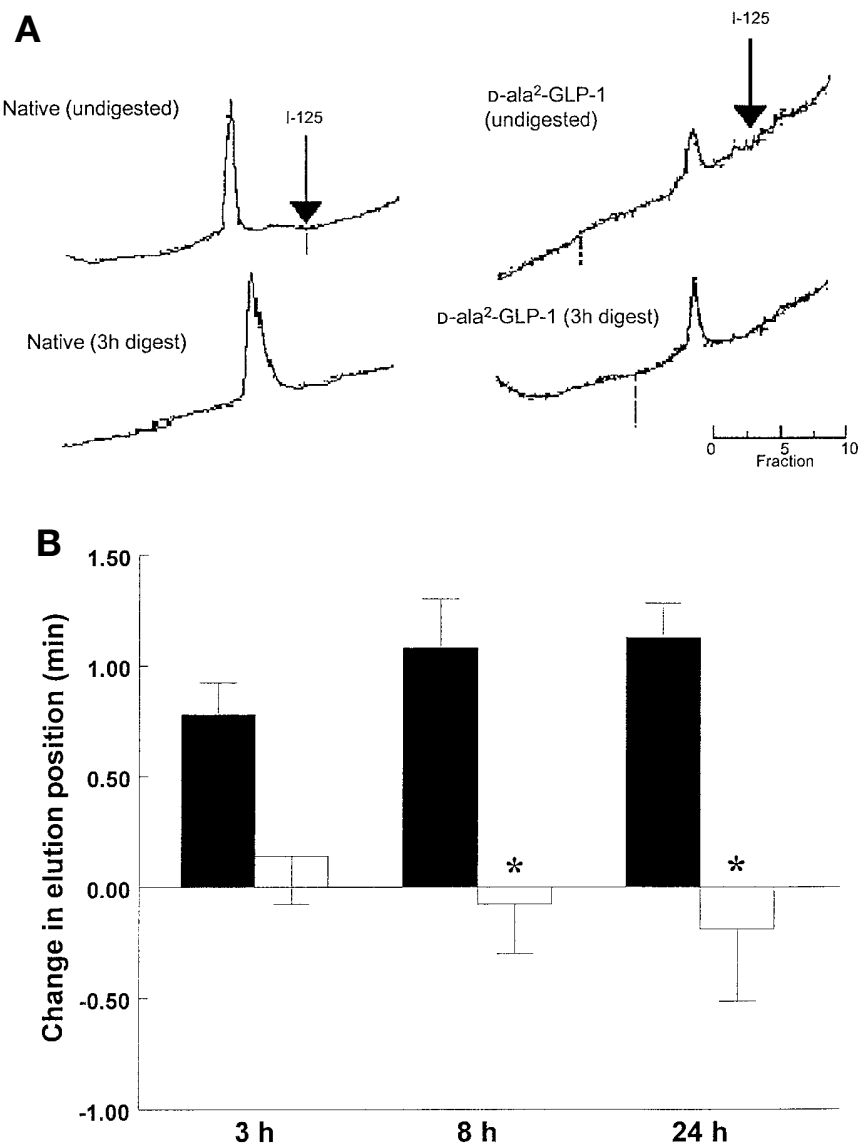

Fig. 1A, B. High-performance liquid chromatography analysis of native GLP-1 and D-ala ${ }^{2}$-GLP-1 after incubation with DP IV in vitro. A Representative $\mathrm{UV}_{214 \mathrm{~nm}}$ profiles of undigested and DP IV-treated native GLP-1 and D-ala ${ }^{2}$-GLP-1 (after a $3 \mathrm{~h}$ digest). I-125 indicates the elution position of the internal standard, ${ }^{125}$ I-GLP-1. B Combined HPLC data for the change in elution position with time of native GLP-1 (closed bars) and D-ala ${ }^{2}$-GLP-1 (open bars). * $p<0.05$ vs native GLP-1 incubated with DP IV in vitro

and this glycaemic response was significantly lower than that found after treatment with the same amount of native GLP-1 $(p<0.001)$.

Treating normal CD1 mice with $\mathrm{D}-$ ala $^{2}-G L P-1$ microspheres. To measure the biological effectiveness of GLP-1 over a period of time that mimics a normal feeding schedule for patients with Type II diabetes, CD1 mice were given repeated oral glucose tolerance tests at $\mathrm{t}=0,4$ and $8 \mathrm{~h}$. Basal blood glucose concentrations for normal CD1 mice given vehicle alone at the time of the $0 \mathrm{~h}$ OGTT did not change significantly over the course of the experiment (Fig. 3), but the glycaemic AUC for vehicle-treated animals rose slightly over the 10-h experiment, from $346 \pm 53$ for the glycaemic responses to oral glucose given at $\mathrm{t}=0 \mathrm{~h}$ to $424 \pm 24$ and $461 \pm 29 \mathrm{mmol} / \mathrm{l} \cdot 120 \mathrm{~min}$ for the tests at $\mathrm{t}=4 \mathrm{~h}$ and $8 \mathrm{~h}$, respectively (Fig. 4). When mice were injected i.p. at $\mathrm{t}=0 \mathrm{~h}$ with $5 \mu \mathrm{g}$ of $\mathrm{D}$-ala ${ }^{2}$ GLP-1, the glycaemic AUC was reduced by 
A

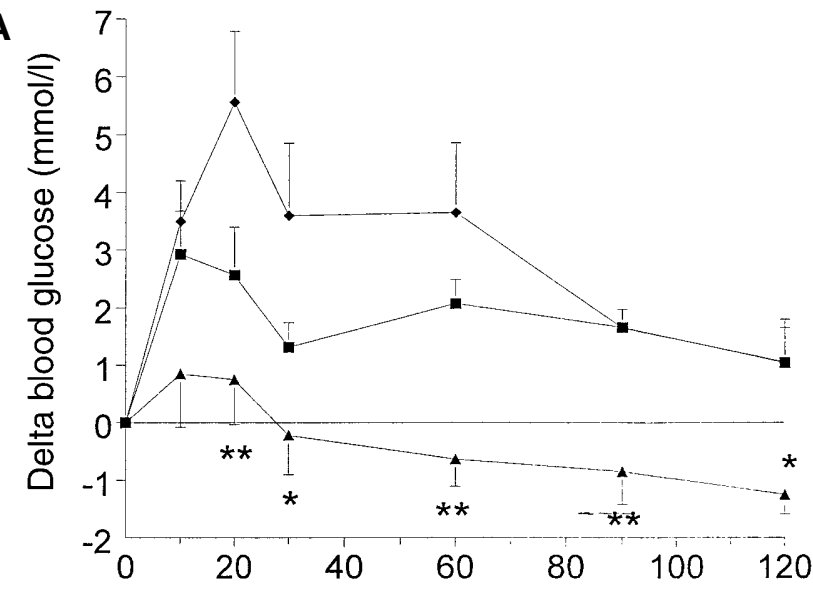

B

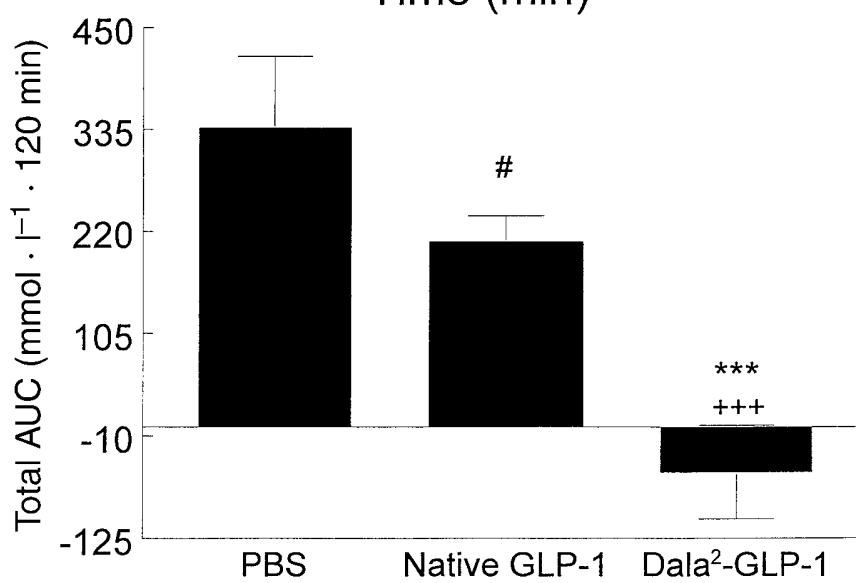

Fig. 2 A, B. Effects of GLP-1 and D-ala ${ }^{2}-$ GLP-1 on the glycaemic response to an oral glucose tolerance test $(1.5 \mathrm{mg}$ glucose/ g body weight) in normal CD1 mice. A Changes in glycaemia in response to s.c. injection (at $t=0 \mathrm{~min}$ ) of PBS ( $\bullet), 10 \mu \mathrm{g}$ native GLP-1 ( $\square)$, or $10 \mu \mathrm{g}$ D-ala ${ }^{2}-G L P-1(\mathbf{A})$. B Area under the curve (AUC) for the glycaemic responses shown in $\mathbf{A}$. * $p<0.05$, ** $p<0.01$, *** $p<0.001$ for $\mathrm{D}-\mathrm{ala}^{2}$-GLP-1 vs PBS; $\# p<0.05$ for GLP-1 vs PBS; and $+++p<0.001$ for $\mathrm{D}-\mathrm{ala}^{2}-$ GLP-1 vs GLP-1

$53 \pm 18 \%$ compared with that of vehicle-treated controls during the 0 -h OGTT $(p<0.05)$. The biological effectiveness of the D-ala ${ }^{2}$-GLP-1 was, however, lost by the 4-h OGTT and the glycaemic AUC at both 4 and $8 \mathrm{~h}$ was no different between mice treated with vehicle alone and those injected with D-ala ${ }^{2}$-GLP-1 at $\mathrm{t}=0 \mathrm{~h}$. To confirm that the response to oral glucose could be lowered by GLP-1 in both of these time periods, mice were also injected with $5 \mu \mathrm{g}$ of $\mathrm{D}^{-\mathrm{ala}^{2}}$ GLP-1 immediately before the 4 or $8 \mathrm{~h}$ OGTT and the glycaemic AUC was calculated. Consistent with the findings for the OGTT at $\mathrm{t}=0 \mathrm{~h}$, injection of $\mathrm{D}$ ala $^{2}-$ GLP- 1 at the time of the OGTT at 4 and $8 \mathrm{~h}$ reduced the subsequent glycaemic AUC by $69 \pm 7 \%$ $(p<0.001)$ and $63 \pm 5 \% \quad(p<0.001)$, respectively compared with vehicle-treated controls.

To establish whether encapsulation of GLP-1 into modified PLGA microspheres permits oral treatment

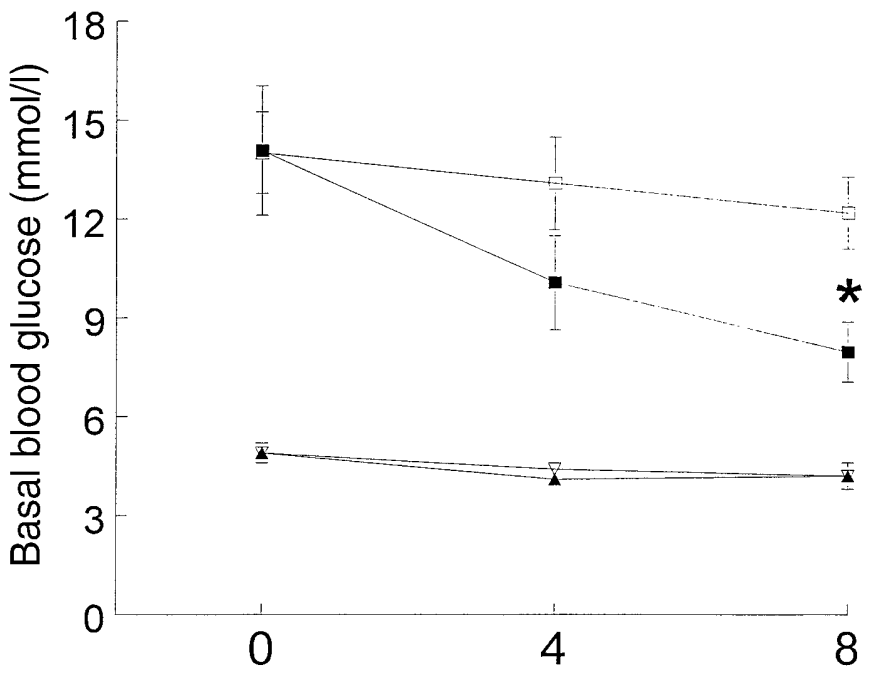

Time (h)

Fig.3. Basal blood glucose values at the beginning of each OGTT (at $\mathrm{t}=0,4$ and $8 \mathrm{~h}$ ) in non-diabetic and diabetic $\mathrm{db} / \mathrm{db}$ mice. All treatments were given at $\mathrm{t}=0 \mathrm{~h} . \triangle \mathrm{\text {:normal }}$ CD1 mice given water (vehicle) or empty microspheres orally $(n=13)$; $\mathbf{\Lambda}$ : normal CD1 mice given D-ala ${ }^{2}$-GLP-1 microspheres orally $(n=9) ; \square: d b / d b$ mice given vehicle orally $(n=9)$ and $\square: d b / d b$ mice given D-ala ${ }^{2}-$ GLP-1 microspheres orally $(n=9)$. * $p<0.05$ for $d b / d b$ mice given $\mathrm{D}^{-a_{a}{ }^{2}-}$ GLP-1 microspheres vs $d b / d b$ mice given vehicle alone

with this peptide hormone, CD1 mice were given $12.5 \mathrm{mg}$ of microspheres [containing either no peptide (empty microspheres) or $250 \mu \mathrm{g}$ of D-ala ${ }^{2}$-GLP$1 ; 2 \%$ loading] orally at $\mathrm{t}=0 \mathrm{~h}$, followed by repeated OGTT at 0,4 and $8 \mathrm{~h}$. The empty microspheres had no effect on glycaemia at any time point. The oral GLP-1 microspheres also had no effect on basal glycaemia at $\mathrm{t}=0,4$ or $8 \mathrm{~h}$ (Fig. 3 ) or on the glycaemic response to oral glucose at $\mathrm{t}=0 \mathrm{~h}$ (Fig. 4). The glycaemic AUC was, however, reduced by the oral $\mathrm{D}-\mathrm{ala}^{2}$ GLP-1-microspheres compared with controls at both 4 and $8 \mathrm{~h}$ (by $41 \pm 12 \%$ at $4 \mathrm{~h}, p<0.05$ and by $19 \pm 11 \%$ at $\mathrm{t}=8 \mathrm{~h}, p<0.05)$. In contrast, oral treatment with $250 \mu \mathrm{g}$ of D-ala ${ }^{2}$-GLP-1 alone, without encapsulation into microspheres, did not alter any of the glycaemic AUC during repeated OGTT in CD1 mice.

As GLP-1 can lower glycaemia through its inhibitory effects on gastric emptying, CD1 mice were given an i.p. injection of vehicle or D-ala ${ }^{2}$-GLP-1 $(5 \mu \mathrm{g})$ or were given oral D-ala ${ }^{2}$-GLP-1-microspheres containing $250 \mu \mathrm{g}$ of peptide or oral D-ala ${ }^{2}$-GLP-1 alone $(250 \mu \mathrm{g})$ at $\mathrm{t}=0 \mathrm{~h}$, and $190 \mathrm{MBq}$ 3-O-Methyl$\mathrm{D}-\left[1{ }^{3} \mathrm{H}\right]$ glucose was added to the glucose gavage at either $\mathrm{t}=0,4$ or $8 \mathrm{~h}$. The results showed no significant effect of any of the treatments on plasma concentrations of ${ }^{3} \mathrm{H}$ at any time point (Fig.5), suggesting that the effects of $\mathrm{D}$-ala ${ }^{2}-\mathrm{GLP}-1$ on glycaemia were not due to alterations in the rate of gastric emptying. 

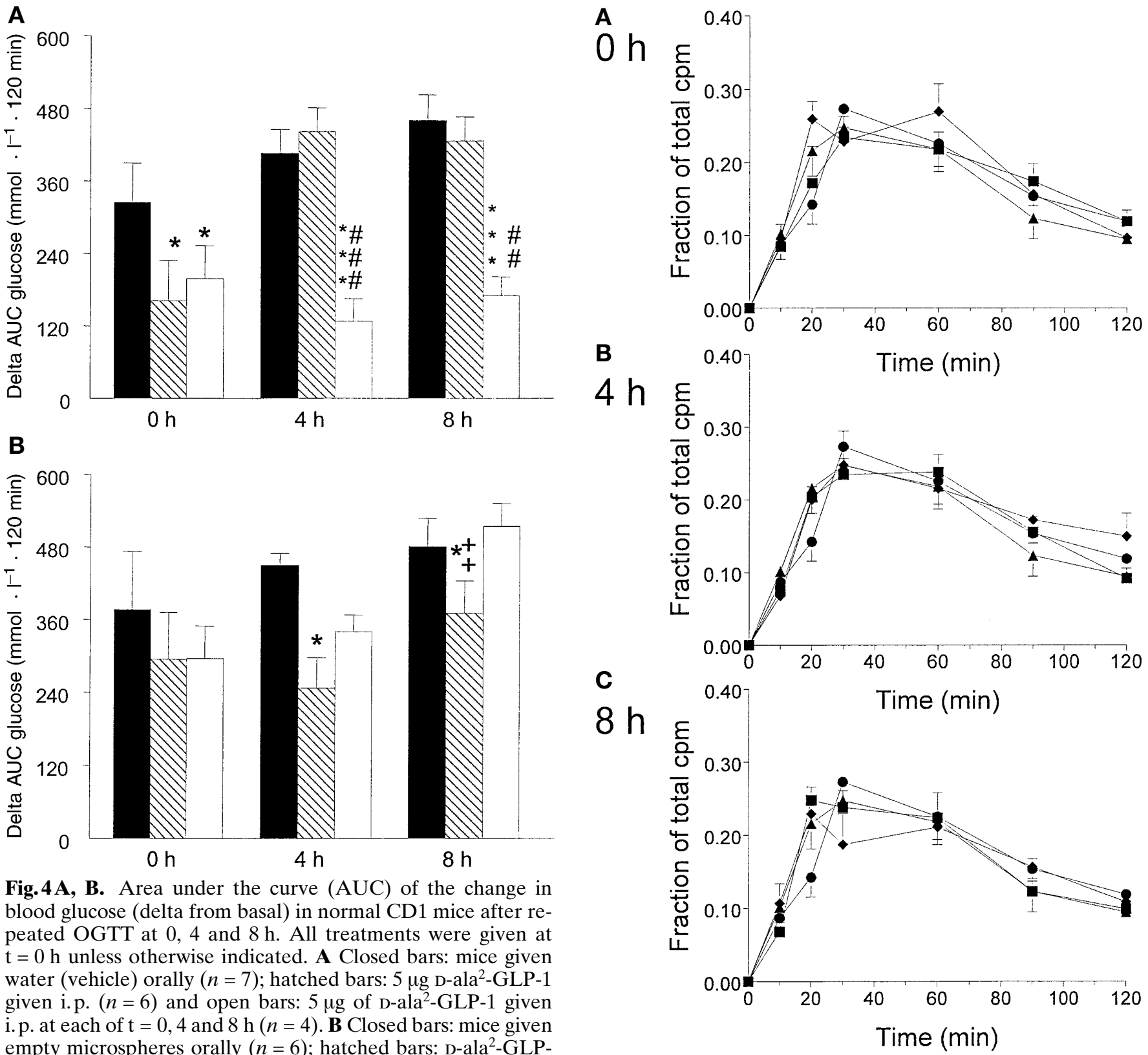

Fig. 4A, B. Area under the curve (AUC) of the change in blood glucose (delta from basal) in normal CD1 mice after repeated OGTT at 0,4 and $8 \mathrm{~h}$. All treatments were given at $\mathrm{t}=0 \mathrm{~h}$ unless otherwise indicated. A Closed bars: mice given water (vehicle) orally $(n=7)$; hatched bars: $5 \mu \mathrm{g}$ D-ala ${ }^{2}$-GLP-1 given i.p. $(n=6)$ and open bars: $5 \mu \mathrm{g}$ of D-ala ${ }^{2}-\mathrm{GLP}-1$ given i.p. at each of $\mathrm{t}=0,4$ and $8 \mathrm{~h}(n=4)$. B Closed bars: mice given empty microspheres orally $(n=6)$; hatched bars: D-ala ${ }^{2}$-GLP1-PLGA-COOH microspheres given orally (equivalent to $250 \mu \mathrm{g}$ of D-ala $\left.{ }^{2}-\mathrm{GLP}-1 ; n=9\right)$ and open bars: $250 \mu \mathrm{g}$ of D-ala ${ }^{2}-$ GLP-1 given orally without microspheres $(n=9)$. * $p<0.05$, *** $p<0.001$ vs control mice. \#\# $p<0.01$, \#\#\# $p<0.001$ vs the response during the same time period in mice receiving $D^{-}$ ala $^{2}$-GLP-1 i.p. at $\mathrm{t}=0 \mathrm{~h}$. $++p<0.01$ vs mice given $\mathrm{D}-\mathrm{ala}^{2}$ GLP-1 orally without microspheres. Basal blood glucose concentrations at 0,4 and $8 \mathrm{~h}$ are shown in Figure $3 \mathrm{~A}$ for mice given vehicle, empty microspheres or D-ala ${ }^{2}$-GLP-1-PLGA$\mathrm{COOH}$ microspheres, and did not differ between any groups of mice

Circulating concentrations of $\mathrm{D}-a a^{2}-G L P-1$. We used a rat model with long-term cannula to measure the circulating concentrations of bioactive GLP-1 after oral treatment with D-ala ${ }^{2}$-GLP-1 microspheres. Basal concentrations of bioactive GLP-1 were no different between animals treated with ve-

Fig.5A-C. Gastric emptying in normal CD1 mice after repeated OGTT at $0(\mathbf{A}), 4(\mathbf{B})$ and $8(\mathbf{C}) \mathrm{h}$. Mice were treated at $\mathrm{t}=0 \mathrm{~h}$ with water (vehicle; ) orally, $5 \mu \mathrm{g}$ D-ala ${ }^{2}$-GLP-1 given i.p. ( ), D-ala ${ }^{2}-$ GLP-1-PLGA-COOH microspheres given orally $(\mathbf{A})$ or D-ala ${ }^{2}$-GLP-1 given orally without microspheres (ם). Gastric emptying was assessed by addition of 3- $O$-methyl- $\left[{ }^{3} \mathrm{H}\right]$-glucose to the glucose gavage at either $\mathrm{t}=0,4$ or $8 \mathrm{~h}$, followed by measurement of changes in plasma concentrations of ${ }^{3} \mathrm{H}$ as a fraction of the total cpm given $(n=4-6)$

hicle, empty microspheres or D-ala ${ }^{2}$-GLP-1 microspheres, averaging $10.3 \pm 2.2 \mathrm{pmol} / \mathrm{l}$ for all rats combined (range $=3.3-16.2 \mathrm{pmol} / \mathrm{l} ; n=7$ ). In the rats treated with vehicle and empty microspheres GLP-1 concentrations fell at $\mathrm{t}=3 \mathrm{~h}$ to $68 \pm 9 \%$ of basal values (results from the two groups of animals were no different and were therefore combined) and remained below basal values until the 


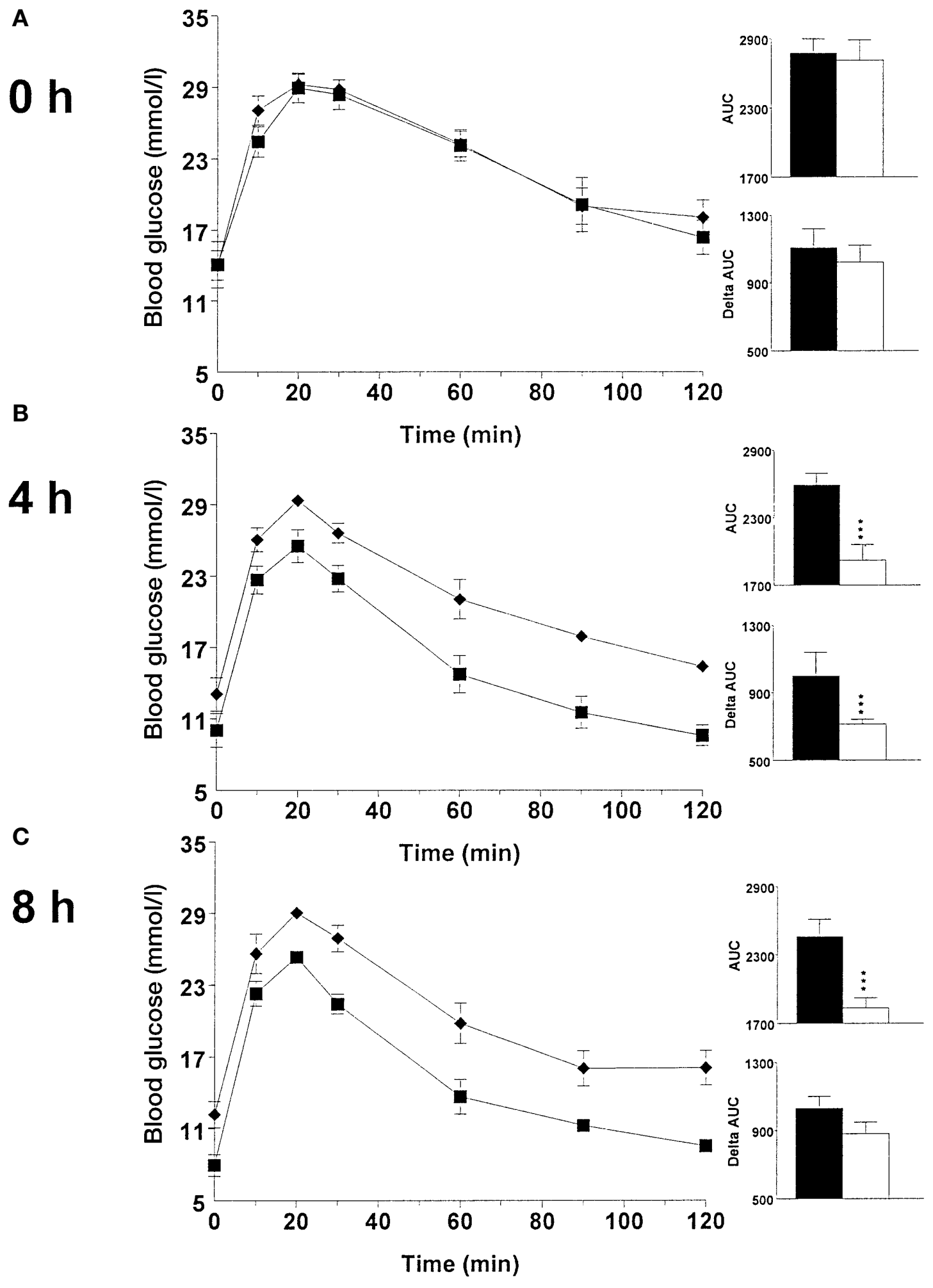

Fig.6A-C. Glycaemic response after repeated OGTT at 0 (A), 4 (B) and 8 (C) $\mathrm{h}$ in diabetic $d b / d b$ mice. Mice were treated at t $=0$ h with water (vehicle; $\diamond ; n=9$ ) or with $12.5 \mathrm{mg}$ of Dala $^{2}$-GLP-1 microspheres given orally $(\square ; n=9)$. Insets AUC for the glycaemic responses and delta AUC for the change in glycaemic response from basal $\left(\mathrm{mmol} \cdot \mathrm{l}^{-1} \cdot 120 \mathrm{~min}\right)$. Closed bars: $d b / d b$ mice receiving no microspheres (controls) and open bars: $d b / d b$ mice given D-ala ${ }^{2}$-GLP-1-microspheres. *** $p<0.001$ vs controls 8-h time point $(p<0.05-0.01)$. In contrast, bioactive GLP-1 concentrations were maintained at $107 \pm$ $32 \%$ of basal between 0 and $8 \mathrm{~h}$ in rats receiving microspheres of $\mathrm{D}-\mathrm{ala}^{2}$-GLP-1 at $\mathrm{t}=0 \mathrm{~h}$, such that circulating GLP-1 concentrations were significantly increased above those of animals treated with vehicle and empty microspheres between $t=3$ and $\mathrm{t}=5 \mathrm{~h}(p<0.05)$. 
Treating diabetic db/db mice with $\mathrm{D}-a_{1}^{2}-G L P-1$ microspheres. As oral D-ala ${ }^{2}$-GLP-1 microspheres effectively reduced the glycaemic response to repeated OGTT in normal, CD1 mice, the ability of the microspheres to lower glycaemia in diabetic animals was also tested, using $d b / d b$ mice. These mice have an inactivating mutation in the leptin receptor causing hyperphagia, obesity and hyperglycaemic, hyperinsulinaemic diabetes at approximately 7-9 weeks of age [29]. When 9-10 week old $d b / d b$ mice were given repeated OGTT at 0,4 and $8 \mathrm{~h}$, basal blood glucose values were found to be in the diabetic range compared with CD1 controls (Fig. 3). Treating $d b / d b$ mice with D-ala ${ }^{2}$-GLP-1 microspheres containing $250 \mu \mathrm{g}$ of peptide at $\mathrm{t}=0 \mathrm{~h}$ followed by repeated OGTT at $\mathrm{t}=0,4$ and $8 \mathrm{~h}$, had no effect at $\mathrm{t}=0 \mathrm{~h}$ but reduced basal glycaemia by $23 \pm 11 \%$ at the 4 -h OGTT (from $13 \pm 1$ to $10 \pm 1 \mathrm{mmol} / \mathrm{l}, p=\mathrm{NS})$ and by $35 \pm 7 \%$ at the 8 -h OGTT (from $12 \pm 1$ to $8 \pm 1 \mathrm{mmol} / 1, p<0.05$ ) compared with $d b / d b$ mice given vehicle alone (Fig. 3). Consistent with the findings in CD1 mice, the glycaemic response to oral glucose at $\mathrm{t}=0 \mathrm{~h}$ for $d b / d b$ mice treated with the D-ala ${ }^{2}$-GLP-1 microspheres was not distinguishable from that of $d b / d b$ mice receiving vehicle alone but shifted considerably downward at both $\mathrm{t}=4$ and $8 \mathrm{~h}$ (Fig. 6). The glycaemic AUC for mice treated with D-ala ${ }^{2}$-GLP-1 microspheres was reduced at the 4 and $8 \mathrm{~h}$ OGTT (by $27 \pm 5 \%$ and $28 \pm 4 \%$, respectively, compared with vehicle-treated $d b / d b$ mice, $p<0.001$, Fig. 6$)$. The delta glycaemic AUC (AUC-independent of the initial basal blood glucose value) was also reduced compared with controls at the 4-h OGTT (by $29 \pm 5 \%$ of vehicle-treated $d b / d b$ mice, $p<0.05)$.

Perfusion of the pancreas from normal CD1 and diabetic $d b / d b$ mice with $\mathrm{D}-a^{2} a^{2}-G L P-1$. In absolute values, the decrease in the AUC for the $d b / d b$ mice treated with D-ala ${ }^{2}$-GLP-1 microspheres was greater than that seen in normal CD1 mice, for the glycaemic response to an OGTT at $\mathrm{t}=4 \mathrm{~h}(p<0.05$; Fig. 6 vs Fig. 4). To find whether this enhanced effectiveness of GLP-1 was due to an increased sensitivity of the beta cell to GLP-1 in $d b / d b$ mice and/or to an enhanced insulinotropic effect of GLP-1 in these mice due to the hyperglycaemia, a perfused pancreas model was established to normalize blood glucose concentrations between the two different animal models. High glucose concentrations alone induced a 1.5-fold increase in insulin secretion from the perfused pancreas of both normal CD1 and diabetic $d b / d b$ mice [from $12.2 \pm 0.1$ to $18.4 \pm 0.2(\mathrm{mg} / \mathrm{ml}) / \mu \mathrm{g}$ total pancreatic insulin in CD1 mice and from $23.9 \pm 0.1$ to $30.7 \pm 0.6(\mathrm{mg} / \mathrm{ml}) / \mu \mathrm{g}$ total pancreatic insulin in $\mathrm{db} /$ $d b$ mice; Fig. 7]. Addition of D-ala ${ }^{2}$-GLP-1 (1 nmol/l) to the high glucose concentration perfusate further increased insulin secretion (to $391 \pm 22 \%$ of controls) in CD1 mice for the first $10 \mathrm{~min}$ of the perfusion peri- od and secretion remained high for the remainder of the study. In contrast, insulin secretion was increased to only $213 \pm 13 \%$ of controls in D-ala ${ }^{2}$-GLP-1-treated $d b / d b$ mice $(p<0.001$ vs the increase seen in CD1 mice), and declined to basal concentrations thereafter.

\section{Discussion}

The major physiological regulator of GLP-1 action is the circulating enzyme DP IV, which cleaves His ${ }^{1}$ ala $^{2}$ from the N-terminus of GLP-1, thereby inactivating the peptide [8-10]. To overcome the short half-life of GLP-1, a DP IV-resistant analogue of GLP-1 was developed by substitution of $\mathrm{D}-\mathrm{ala}^{2}$ for Lala $^{2}$. The D-ala ${ }^{2}$-GLP-1 analogue stimulated insulin secretion in a mouse perfused pancreas model and was more potent than the native peptide in lowering the glycaemic response to an OGTT. This peptide does not have enhanced GLP-1 receptor binding or activation [30]. These findings therefore suggest that the enhanced ability of D-ala ${ }^{2}$-GLP-1 to lower glycaemia in mice in vivo is attributable to its ability to stimulate insulin secretion for a prolonged period of time. Even with resistance to DP IV cleavage, the biological activity of D-ala ${ }^{2}$-GLP-1 was, however, lost within $4 \mathrm{~h}$ after treating mice, probably due to renal clearance of the peptide [31]. Thus, frequent injections or continuous infusion of the peptide are required if Dala $^{2}$-GLP-1 is to be useful as a therapeutic agent in the treatment of Type II diabetes.

To avoid the need for repeated injections of GLP1 , an oral delivery system was designed using a biodegradable and biocompatible polymer, PLGA$\mathrm{COOH}$. Although a number of investigators have used PLGA and related polymers for oral peptide delivery $[21,22,32]$, several aspects of the present study warrant discussion. Firstly, no previous study has reported on the use of PLGA-COOH as the base polymer for microsphere preparation. The addition of a - $\mathrm{COOH}$ end group decreases the passage of microspheres through the gastrointestinal tract, thus increasing their chance of being absorbed [33-35]. Secondly, although PLGA has been shown to be taken up into the systemic circulation [21,32], this has not previously been established for PLGA-COOH. The use of PLGA-COOH alone probably does not, however, permit release of peptide within a time frame that is reasonable for peptide therapeutics, as PLGA has a half-life of approximately 3.3 years [36]. One preferred time frame for the delivery of GLP-1 to patients with Type II diabetes would be over a period of 9-12 h, which would permit twice-daily dosing to maintain therapeutic concentrations of GLP-1 whilst preventing any potential long-term consequences of a very long duration-of-action therapeutic. Therefore, to enhance the rate of release of peptide, the 

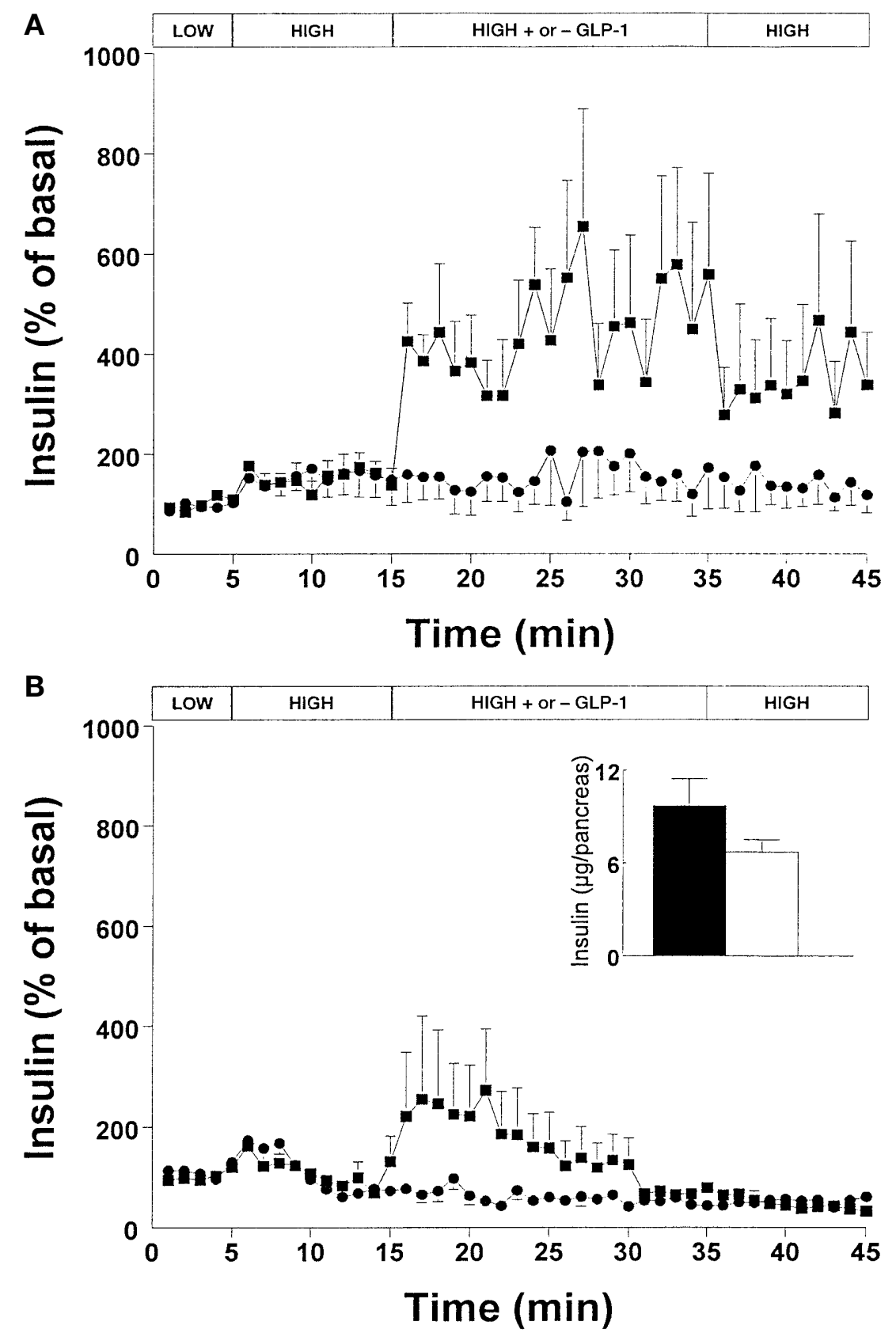

Fig. $7 \mathbf{A}$, B. Insulin secretion by the perfused pancreas, in response to low $(1.4 \mathrm{mmol} / \mathrm{l})$ and high $(20 \mathrm{mmol} / \mathrm{l})$ glucose, in the absence $(\mathbf{O})$ or presence $(\boldsymbol{\square})$ of $1 \mathrm{nmol} / \mathrm{l}$ D-ala ${ }^{2}$-GLP-1. A Pancreas from normal CD1 mice $(n=6)$ and $\mathbf{B}$ pancreas from diabetic $d b / d b$ mice $(n=8)$. Data are expressed as the percent of basal, where basal was calculated as the mean insulin secretion over the first 5 min of infusion with low glucose. Inset Pancreatic insulin content (in $\mu \mathrm{g} /$ pancreas) at the end of the perfusion period. Closed bar: CD1 mice and open bar: $d b /$ $d b$ mice

biocompatible compound olive oil was added during preparation of the PLGA-COOH microcapsules.

In vivo studies clearly indicated that bioactive $\mathrm{D}$ ala ${ }^{2}-$ GLP-1 was released into the circulation of mice after oral treatment with microspheres (consisting of
$48 \%$ PLGA-COOH, $50 \%$ olive oil and $2 \%$ peptide) as assessed by the ability of the D-ala ${ }^{2}$-GLP-1 microspheres to reduce the glycaemic response to oral glucose. Analysis of bioactive GLP-1 concentrations also indicated an increase in circulating peptide concentrations $3-5 \mathrm{~h}$ after oral treatment with $\mathrm{D}$-ala ${ }^{2}$ GLP-1 microspheres. Due to the low cross-reactivity of D-ala ${ }^{2}$-GLP-1 in this assay, the actual increase cannot, however, reliably be quantified. Nonetheless, the results indicate that the microspheres were necessary for the oral delivery of bioactive D-ala ${ }^{2}$-GLP-1 because the peptide did not elicit a biological response after oral treatment with the peptide without prior encapsulation into microspheres. The time course of action for D-ala ${ }^{2}$-GLP-1 delivered orally in microspheres differed considerably from that of in- 
jected peptide, such that a delayed but much more prolonged duration of action (at least $10 \mathrm{~h}$ ) was observed for the D-ala ${ }^{2}$-GLP-1 microspheres. The amount of biologically active peptide available during the OGTT at $\mathrm{t}=4 \mathrm{~h}$ in mice treated with microspheres containing $250 \mu \mathrm{g}$ of D-ala ${ }^{2}$-GLP-1 was approximately $5 \mu \mathrm{g}$ of peptide, as determined by comparing the glycaemic response of oral microspheres during the $\mathrm{t}=4 \mathrm{~h}$ OGTT to that of mice treated with $5 \mu \mathrm{g}$ of $\mathrm{D}-\mathrm{ala}^{2}$-GLP-1 i.p. at $\mathrm{t}=4 \mathrm{~h}$. A similar but slightly reduced response was seen during the OGTT at $\mathrm{t}=8 \mathrm{~h}$. Therefore, in normal CD1 mice, microspheres composed of $50 \%$ PLGA-COOH, $48 \%$ olive oil and $2 \%$ D-ala ${ }^{2}-$ GLP-1 permitted oral delivery of therapeutic concentrations of the peptide over a 10 -h period equivalent to repeated injections of $5 \mu \mathrm{g}$ of D-ala ${ }^{2}$-GLP-1 (representing approximately $1-2 \%$ of the total peptide given in the microspheres at each of $\mathrm{t}=4$ and $8 \mathrm{~h}$ ). Although both the total duration of action and the dynamics of the peptide release from the microspheres in vivo still remain to be completely established, the effectiveness of the Dala $^{2}$-GLP-1-microspheres over a 10 -h period is ideal for the delivery of a therapeutic peptide that is required continuously.

In addition to non-diabetic mice, D-ala ${ }^{2}$-GLP-1PLGA-COOH microspheres were also given to $d b /$ $d b$ mice, a model of Type II diabetes. In contrast to the CD1 mice, a downward shift in basal glycaemia towards normal was observed in $d b / d b$ mice treated D-ala ${ }^{2}$-GLP-1 microspheres compared with $d b / d b$ mice that received vehicle alone. This decrease in glycaemia accounts in part for the reduced glycaemic AUC seen in the $d b / d b$ mice at both $\mathrm{t}=4$ and $8 \mathrm{~h}$. The total increment in glycaemia relative to basal (e.g. delta AUC) was, however, also reduced in $d b /$ $d b$ mice at $\mathrm{t}=4 \mathrm{~h}$ by treatment with $\mathrm{D}-\mathrm{ala}^{2}$-GLP-1PLGA-COOH microspheres, indicative of an additional effect on the glycaemic response to oral glucose. As the pancreas from $d b / d b$ mice had a reduced relative response to $\mathrm{D}-\mathrm{ala}^{2}$-GLP-1 treatment in vitro, these findings further suggest that the prolonged effect of the D-ala ${ }^{2}$-GLP-1-microspheres in $d b / d b$ mice was due to the glucose-dependent insulinotropic effects of GLP-1 on the beta cell.

The D-ala ${ }^{2}$-GLP-1 given to mice in our study lowered glycaemia with no detectable effect on gastric emptying. Previous studies in humans have similarly found dissociation between the effects of GLP-1 on gastric emptying and on insulin secretion in normal humans [37]. Thus, it seems that treatment with GLP-1 can be titrated so as to permit the effects on glycaemia but preventing the occurrence of gastric side-effects, which include stasis, nausea and vomiting [6]. Additionally, the results of such studies show that humans have a 150 -fold to 300 -fold increased sensitivity to the biological effects of GLP-1 compared with mice. Thus, doses of GLP-1 as low as $0.5 \mathrm{nmol} / \mathrm{kg}$ s.c. (equivalent to $1.6 \mathrm{ng} / \mathrm{g}$ ), have been shown to lower glycaemic excursions in response to an intravenous glucose tolerance test in humans [6] whereas a minimum dose of 5-10 $\mu \mathrm{g}$ s.c. (equivalent to $250-500 \mathrm{ng} / \mathrm{g}$ ) is required for similar effects in mice receiving an OGTT [30]. These findings suggest that the amount of GLP-1 in microsphere preparations required for therapeutic use in humans is likely to be considerably lower than that required for the normal and diabetic mice used in our study.

There are four proposed sites of absorption of microspheres of different sizes, including the villus tips $(<150 \mu \mathrm{m})$, intestinal macrophages $(<1 \mu \mathrm{m})$, enterocytes $(<200 \mathrm{~nm})$ and Peyer's patches $(<10 \mu \mathrm{m})$. Although all of these sites probably play parts, the major site of absorption of most microparticles, including PLGA microspheres of $1-5 \mu \mathrm{m}$ in size, has been suggested to be Peyer's patches [32, 38-42]. After absorption, PLGA microspheres have been found in the lymph nodes, spleen, kidneys and liver [32]. The microspheres produced in our study were approximately $1 \mu \mathrm{m}$ in size, consistent with their being suitable for absorption across the gastrointestinal tract.

The results of our study have shown that D-ala ${ }^{2}$ GLP-1 is more potent than native GLP-1 at lowering the glycaemic response to oral glucose in normal mice, probably due to its DP IV-resistance. A delivery system for this peptide, using microspheres composed of PLGA-COOH and olive oil, effects a reduced glycaemic response to repeated OGTT over a 10-h time period when given orally to normal and diabetic $d b / d b$ mice and statistically significantly reduces basal glycaemia in the diabetic mice. Oral delivery of therapeutic peptides can therefore be accomplished through an approach to encapsulate peptides within biocompatible PLGA-COOH-olive oil microspheres.

Acknowledgements. The authors are grateful to J. Giguere for assistance with the peptide synthesis. J. W. Joseph was the recipient of graduate studentships from the Banting and Best Diabetes Centre, University of Toronto and from the Department of Physiology (University of Toronto 'Open' Fellowship). This work was supported by a 'Mr. \& Mrs. William McTavish' grant from the Canadian Diabetes Association (to P.L. Brubaker). Patents are pending in Canada and the United States on the method for encapsulation of therapeutic peptides into microspheres.

\section{References}

1. Drucker DJ (1998) Glucagon-like peptides. Diabetes 47: 159-169

2. Nauck MA, Holst JJ, Willms B, Schmiegel W (1997) Glucagon-like peptide 1 (GLP-1) as a new therapeutic approach for Type 2-diabetes. Exp Clin Endocrinol Diabetes 105: $187-195$ 
3. Drucker DJ, Philippe J, Mojsov S, Chick WL, Habener JF (1987) Glucagon-like peptide I stimulates insulin gene expression and increases cyclic AMP levels in a rat islet cell line. Proc Natl Acad Sci USA 84: 3434-3438

4. Kreymann B, Ghatei MA, Williams G, Bloom SR (1987) Glucagon-like peptide-1 7-36: A physiological incretin in man. Lancet ii: $1300-1304$

5. Gutniak M, Orskov C, Holst JJ, Ahrén B, Efendic S (1992) Antidiabetogenic effect of glucagon-like peptide-1 (7-36)amide in normal subjects and patients with diabetes mellitus. New Engl J Med 326: 1316-1322

6. Ritzel R, Orskov C, Holst JJ, Nauck MA (1995) Pharmacokinetic, insulinotropic, and glucagonostatic properties of GLP-1 [7-36 amide] after subcutaneous injection in healthy volunteers. Dose-response-relationships. Diabetologia 38: 720-725

7. Holz GG, Kühtreiber WM, Habener JF (1993) Pancreatic beta-cells are rendered glucose-competent by the insulinotropic hormone glucagon-like peptide-1(7-37). Nature 361: 362-365

8. Deacon CF, Knudsen LB, Madsen K, Wiberg FC, Jacobsen O, Holst JJ (1998) Dipeptidyl peptidase IV resistant analogues of glucagon-like peptide-1 which have extended metabolic stability and improved biological activity. Diabetologia 41: 271-278

9. Mentlein R, Gallwitz B, Schmidt WE (1993) Dipeptidyl-peptidase IV hydrolyses gastric inhibitory polypeptide, glucagonlike peptide-1(7-36)amide, peptide histidine methionine and is responsible for their degradation in human serum. Eur J Biochem 214: 829-835

10. Kieffer TJ, McIntosh CH, Pederson RA (1995) Degradation of glucose-dependent insulinotropic polypeptide and truncated glucagon-like peptide 1 in vitro and in vivo by dipeptidyl peptidase IV. Endocrinology 136: 3585-3596

11. Willms B, Idowu K, Holst JJ, Creutzfeldt W, Nauck MA (1998) Overnight GLP-1 normalizes fasting but not daytime plasma glucose levels in NIDDM patients. Exp Clin Endocrinol Diabetes 106: 103-107

12. Wearley LL (1991) Recent progress in protein and peptide delivery by noninvasive routes. Crit Rev Ther Drug Carries Syst 8: 331-394

13. Banga AK, Chien YW (1988) Systemic delivery of therapeutic peptides and proteins. Int J Pharmacol 48 : 15-50

14. Cramer MP, Saks SR (1994) Translating safety, efficacy and compliance into economic value for controlled release dosage forms. Pharmacoeconomics 5: 482-504

15. Pereswetoff-Morath L (1998) Microspheres as nasal drug delivery systems. Adv Drug Del Rev 29: 185-194

16. Critchley H, Davis SS, Farraj NF, Illum L (1994) Nasal absorption of desmopressin in rats and sheep. Effects of a bioadhesive microsphere delivery system. J Pharm Pharmacol 46: 651-656

17. Ishida M, Machida Y, Nambu N, Nagai T (1981) New mucosal dosage form of insulin. Chem Pharm Bull (Tokyo) 29: 810-816

18. Ando T, Maitani Y, Yamamoto T, Takayama K, Nagai T (1998) Nasal insulin delivery in rabbits using soybean-derived sterylglucoside and sterol mixtures as novel enhancers in suspension dosage forms. Biol Pharm Bull 21: 862-865

19. Gutniak M, Larsson H, Sanders SW, Juneskans O, Holst JJ, Ahrén B (1998) GLP-1 tablet in Type 2 diabetes in fasting and postprandial conditions. Diabetes Care 20: 1874-1879

20. Hermens WAJJ, Merkus FWHM (1988) The influence of drugs on nasal ciliary movement. Pharm Res 4: 445-449

21. Mathiowitz E, Jacob JS, Jong YS et al. (1997) Biologically erodable microspheres as potential oral drug delivery systems. Nature 386: 410-414

22. Ignatius AA, Claes LE (1996) In vitro biocompatability of bioresorbable polymers: Poly(L, DL-lactide) and poly(L-lactide-co-glycolide). Biomaterials 17: 831-839
23. Merrifield RB (1963) Solid phase peptide synthesis. The synthesis of a tetrapeptide. J Am Chem Soc 85: 2149-2154

24. Boulanger Y, Khiat A, Larocque A, Fournier A, St-Pierre S (1996) Structural comparison of alanine-substituted analogues of the calcitonin gene-related peptide 8-37. Importance of the C-terminal segment for antagonistic activity. Int J Pept Protein Res 47: 477-483

25. Tucker JD, Dhanvantari S, Brubaker PL (1996) Proglucagon processing in islet and intestinal cell lines. Regul Pept 62: 29-35

26. Gedulin BR, Young AA (1998) Hypoglycemia overrides amylin-mediated regulation of gastric emptying in rats. Diabetes 47: 93-97

27. Pederson RA, Satkunarajah M, McIntosh CH et al. (1998) Enhanced glucose-dependent insulinotropic polypeptide secretion and insulinotropic action in glucagon-like peptide 1 receptor (-/-) mice. Diabetes 47: 1046-1052

28. Drucker DJ, Campos R, Reynolds R, Stobie K, Brubaker PL (1991) The rat glucagon gene is regulated by a protein kinase A-dependent pathway in pancreatic islet cells. Endocrinology 128: 394-400

29. Coleman DL (1978) Obese and diabetes: Two mutant genes causing diabetes-obesity syndrome in mice. Diabetologia 14: 141-148

30. Jeng W, Chernenko J, Giguere J et al. (1998) Biological activities of modified GLP-1. The Endocrine Society, Bethesda, p2-p98

31. Ruiz-Grande C, Pintado J, Alarcón C, Castilla C, Valverde I, López-Novoa JM (1990) Renal catabolism of human glucagon-like peptides 1 and 2. Can J Physiol Pharmacol 68: $1568-1573$

32. Damge C, Aprahamian M, Marchais H, Benoit JP, Pinget M (1996) Intestinal aborption of PLAGA microspheres in the rat. J Anat 189: 491-501

33. Chickering DE, Mathiowitz E (1995) Bioadhesive microspheres. I. A novel electrobalance-based method to study adhesive interactions between individual microspheres and intestinal mucosa. Journal of Controlled Release 34: 251-261

34. Chickering DE 3rd, Jacob JS, Mathiowitz E (1995) Bioadhesive microspheres. II. Characterization and evaluation of bioadhesion involving hard, bioerodible polymers and soft tissue. Reactive and Functional Polymers 25: 189-206

35. Frisbie CD, Rozsnyai F, Noy A, Wrighton MS, Lieber CM (1994) Functional group imaging by chemical force microscopy. Science 265: 2071-2074

36. Bergsma JE, de Bruijn WC, Rozema FR, Bos RR, Boering G (1995) Late degradation tissue response to poly(L-lactide) bone plates and screws. Biomaterials 16: 25-31

37. Schirra J, Kuwert P, Wank U et al. (1997) Differential effects of subcutaneous GLP-1 on gastric emptying, antroduodenal motility, and pancreatic function in men. Proc Assoc Am Physicians 109: 84-97

38. O'Hagan DT (1996) The intestinal uptake of particles and the implications for drug and antigen delivery. J Anat 189: 477-482

39. Hillery AM, Jani PU, Florence AT (1994) Comparative, quantitative study of lymphoid and non-lymphoid uptake of $60 \mathrm{~nm}$ polystyrene particles. J Drug Target 2: 151-156

40. LeFevre ME, Hancock DC, Joel DD (1980) Intestinal barrier to large particulates in mice. J Toxicol Environ Health 6: 691-704

41. Eldridge JH, Hammond CJ, Meulbroek JA, Staas JK, Gilley RM, Tice TR (1990) Controlled release in the gut associated lymphoid tissue. I. Orally administered biodegradable microspheres target the Peyer's patches. Journal of Controlled Release 11: 205-214

42. Jenkins PG, Howard KA, Blackhall NW, Thomas NW, Davis SS, O'Hagan DT (1994) Microparticulate absorption from the rat intestine. Journal of Controlled Release 29: 339-350 